Vol. 7 No. 3, 2021

\title{
GREEN ECONOMY DEVELOPMENT: METHODOLOGICAL APPROACH
}

\author{
Veronika Chala', Yuliia Orlovska ${ }^{2}$
}

\begin{abstract}
The subject of this study is the principles, factors and features of the green economy as a complex multicomponent system. It was important to clarify the ontology of the term "development" and to propose a methodology for filling the meaning of this term with a specific scientific approach, which consisted in identifying factors that shape directed, natural (regular) and inevitable changes as mandatory elements of development in the philosophical sense of the latter. The article analyzes different approaches to the definition of green economy, which gave the authors a reason to propose their own perception of the green economy as a socio-eco-economic system, which should be simultaneous under directed, natural (regular) and inevitable changes to ensure its development. The authors dwelled on the characteristics of each of the three mandatory changes. Directed changes in the green economy as a system were considered through the prism of seventeen goals of sustainable development (defining those for which the green economy "works" directly), which form new requirements for key components of the economic system: production, exchange, distribution and consumption. Regular changes are characterized as those that correspond or do not contradict the basic economic laws of the post-industrial era and form the ecological basis for the competitiveness of the economy. Irreversibility of change is defined as justified regulatory measures of strict environmental and economic policy, based on the methodological, proven by scientists, the principle of regulation in a mixed economic system and the abandonment of free market mechanisms (which "does not work" to achieve sustainable development). The authors have proposed a system-hierarchical approach to ensuring intermediate principles of green economy development as a system (direction, regularity and irreversibility of changes) and their integral effect on the quality of sustainable development of the social system as a whole. Further directions of research of system principles of development of green economy have been defined as well.
\end{abstract}

Key words: green economy, sustainability, development, socio-eco-economic system.

JEL Classification: Q01, Q56

\section{Introduction}

Economic activity has long caused significant environmental damage to the planet. Mankind, in its desire to produce and consume in ever-decreasing volumes, today lives "in the debt" of future generations, which goes completely against the postulates of sustainable development, to which the governments of most countries declared almost 40 years ago at the International Summit on environmental protection (known as the 1992 UN Conference). Scientists predicted a significant shortage of key resources, such as oil, in 2011 (Global Green Economy, 2011). And although this forecast for global carbohydrate shortages has not yet come true (as of 2021), we are witnessing constant natural disasters caused by environmental and economic imbalances, and their number and scale are only increasing. The work of scientists of the last two decades within the new economic science green economy - is aimed at solving both theoretical and practical problems of balancing economic growth (rather, slowing it down) with efficient use of natural resources, reducing emissions and achieving social justice. The theory of the "green" economy is based on the following axioms: all surfaces of the Earth are interconnected; it is impossible to demand the satisfaction of infinitely growing needs in conditions of limited resources; it is impossible to infinitely expand the sphere of influence in a limited space. The exacerbation of global environmental problems, which is mainly caused by the so-called "Decoupling Effect” (Anikina I., Anikin A.; Nozhkina, N., 2017), when natural resources are reduced and consumption increases - has jeopardized the very existence of human civilization and therefore, it intensified the search for

\footnotetext{
Corresponding author:

${ }^{1}$ Kyiv National Economic University named after Vadym Hetman, Ukraine.

E-mail: v4alaya@gmail.com

ORCID: https://orcid.org/0000-0002-2233-2335

${ }^{2}$ Prydniprovska State Academy of Civil Engineering and Architecture, Ukraine.

E-mail: juliaorlov@ukr.net

ORCID: https://orcid.org/0000-0002-5915-4261
} 
new ways of further development of the world economy as an "environmentally friendly" green economy.

The "green" economy, in contrast to the traditional economy, arose not from abstract theories, but from the practical activities of environmentalists and "green" political parties (Melnik, 2018). Dozens of researchers from different countries (including foreign and domestic scientists Allen C., Anikina I., Anikin A., Atkisson A., Nozhkina N., Pearce D., Markandya A., Barbier E., Galushkina T., Kostetska K., Chmyr O., Zakharkevich N., Potapenko V., Marchenko O., Mamaliga V., Garlytska D., Berezhna Yu., Melnik L., Vukovic N., Pobedinsky V., Mityagin S., Drozhzhin A., Mingaleva Zh., Burkart K., Clift R., Wright L. and others, as well as international institutions (United Nations Environment Program (UNEP), Organization for Economic Co-operation and Development (OECD), IFOAM, International Federation of Organic Agriculture Movements, etc.)) continue intensive work in various areas of socioeco-economic research of the green economy. At the same time, given the history of the green economy as a science, we should talk about the lack not so much of theoretical approaches to its description, as the methodological basis for ensuring the development of the green economy as a practice needed. The question of what constitutes such a development of the green economy, what are its main features and factors that ensure this development, have formed the main idea and content of this article.

\section{Aim and tasks of the article}

The aim of the article is to generalize approaches to defining the key features, advantages of green economy development in a single methodological context of philosophical perception of development as directed, regular and irreversible changes in structural elements of the system and connections between elements of green economy as a system. Accordingly, the objectives of the article were a comprehensive methodological approach: characterization of the green economy as a system, as well as the definition of 1) directions and goals of change; 2 ) features of regularity of changes and 3 ) criteria of irreversibility of changes as components of green economy development.

\section{Green economy as a system}

The plan of the study of the green economy developed was based on the discovery of the ontological meaning of the term "development", for which the general scientific (philosophical) meaning of this term was studied. The authors of the Philosophical Encyclopedic Dictionary (1983) characterize development as "an inevitable, directed, regular change of material and ideal objects" (p. 561 - hereinafter our translation, V.Ch., Yu.O.) and emphasize that only the simultaneous presence of all three of these properties distinguish the processes of development among other changes. It is because, for example, the reversibility of changes characterizes the processes of functioning (such as cyclic reproduction of a constant system of functions). In turn, the lack of patterns is characteristic of random processes, and in the absence of direction, changes cannot accumulate, and therefore the process itself loses the unique, internally interconnected line. That is why when studying the development of such a complex system as the green economy, it is necessary to determine both its main structural features and all three characteristics of changes in its elements and the relationships between them.

The definition of the structural elements of the green economy should be based on its definition in the scientific literature. In this aspect, it should be noted that today there is a significant range of approaches to the definition of a green economy, and therefore, the definitions themselves.

It is believed that the term "green economy" was first used in 1989 in a report by environmental economists (Pearce, Markandya, Barbier, 1989), for the British government. Later, D. Pearce published reports "Greening the world economy" (Pearce, 1990) and "Measuring Sustainable Development" (Pearce, 1994). If the main idea of the first report was to help the economy implement environmental policy, then further emphasis was placed on global environmental issues (climate change, ozone depletion, deforestation, loss of natural resources in developing countries) and the need to revise the traditional economic model of development (Allen, 2012).

The most established definitions of the green economy are those that consider it: 1) as a scientific concept aimed (according to the UN) at achieving convergence between the three components of sustainable development (noted in: Galushkina, Kostecka, 2012); 2) the economy, which differs in terms of ensuring economic and social progress on the basis of environmentally friendly activities (Chmyr, Zakharkevich, 2013); 3) as a way to implement a course for sustainable development (Potapenko, 2014); 4) as a process of transformation that eliminates imbalances and dysfunctions of the modern economy (DORE, e-source); 5) as a "flexible" economy that provides a better quality of life for all within the existing environmental constraints on the planet (Benson E, e-source); 6) as an economy with low greenhouse gas emissions, efficient use of resources and taking into account the interests of society, as well as within which it is believed that the economy is a dependent component of the natural environment (Marchenko, Mamaliga, 2019). The approach of the International Chamber of Commerce (ICC) to defining this type of economy as one where economic growth and environmental responsibility complement each other, supporting 
progress in social development (ICC, e-source) is well known.

We propose to consider the green economy through the prism of the basic structural and reproductive content of the economy as interconnected processes of production, exchange, distribution and consumption of such products (goods, services), which are characterized by minimal resource intensity (especially non-renewable resources) and reduced negative impact on nature in the form of future waste and (or) emissions in the process of production and consumption. This systemic approach allows us to perceive the green economy as a system that has both internal and external (regulatory) influences that shape its directed, regular and inevitable changes that is, its development.

\section{Directed changes of green economy system}

Directed changes in the green economy as a system must coincide with the 17 global goals of sustainable development ("Green Wave", 2016). It should be noted that among these goals of sustainable development of the planet, agreed at the Summit on Sustainable Development in 2015 as a continuation of the Millennium Development Program, the majority (namely: 14) are those that should be aimed at the practical implementation of green economy and green growth: a world without poverty; healthy lifestyle; high level education; access to clean water and sewage; alternative energy sources; decent jobs and economic growth; innovation and infrastructure; a world without inequality; urban security and affordable housing; reasonable consumption; combating climate change; conservation of marine resources; conservation of the ecosystem on land.

The above goals of sustainable development, achieved through the development of areen economy, contribute to its goal - to create an effective environment for economic and social progress, based on minimizing the negative impact on the environment and efficient use of natural resources while maintaining a decent standard of living.

For example, the South African Green Economy Strategy states that its implementation certainly creates such positive effects as increased economic activity and the use of cleaner technologies with low carbon emissions and minimal impact on the environment (South Africa's Green Economy Strategy, e-source).

Thus, the concept of directed changes of the "green economy" as a system implies a strategic implementation aimed at systemic global challenges the highest level of implementation of the paradigm and strategy of sustainable development. The traditional, "brown" economy has its main sectors focused on "landscaping" programs and these are also promising Directed Changes of the Green Economy System. Potapenko V. provides convincing economic and social arguments of UN experts in favor of investing $2 \%$ of world GDP in "greening" the ten most important sectors of the economy to change the nature of development and direct public and private capital flows to reduce carbon emissions and efficient use of resources (Potapenko, 2014). Such transformations stimulate economic activity at least in the same way as conventional investment strategies, but with less risk of crises and shocks. It is a way to implement the course of sustainable development at the national, regional and global levels, which is consistent with the "Agenda for the XXI century" and simplifies the implementation of its provisions. The transition to a green economy has already begun, it lasts for about two decades, and it is now crucial to maintain this momentum, directing it in the regular changes (Regular Changes of Green Economy System), along with the directional changes mentioned above (Directed Changes of Green Economy System).

\section{Regular changes of green economy system}

It should be noted that modern scientists often equate the concept of "green economy" and "low-carbon economy” (for example, Garlytska, 2017). The name "low-carbon economy" directs scientific thought and economic policy to help reduce $\mathrm{CO} 2$ emissions, and therefore - to reduce carbohydrate consumption, and to replace them with renewable energy resources, and to ensure healthy air and a healthy lifestyle in general. Accordingly, processes of production, exchange, consumption have been becoming more "green". "Greening" the process of distribution of wealth is largely the result of strict ecological economic policy (as Irreversible Changes element for Green Economy development, which will be discussed below).

The transition to a low-carbon economy involves structural and systemic reformatting of national financial and economic systems in response to green regulation. Naturally, changes are reflected in the level of competitiveness of the economy. Indeed, the quality of life of the population, which largely depends on the quality of the environment and creates conditions for increasing productivity, as well as the obvious growth of population demand for "environmental" goods and services, form theenvironmental componentofeconomic development and international competitiveness. This in turn, requires the inclusion of the concepts of "green" economy and sustainable development in the concept of international competitiveness. In this context, we consider it appropriate to state that "... there is a need for research initiatives to develop a new concept of sustainable competitiveness in the context of globalization with an emphasis on how sustainable development interacts with competitiveness" (Balkyt, Tvaronavičien, e-source).

It should be noted that among international organizations, the World Economic Forum pays 
most attention to the development of the concept of "sustainable competitiveness", which defines this concept as a set of institutions, policies and factors that maintain the productivity of the nation's economy over time, ensuring social and environmental sustainability (WEF, e-source). In our opinion, this definition is very successful, as it combines the main goal of increasing competitiveness - to achieve a high level and quality of life, as it is possible only in compliance with the principle of the trinity of development: social, economic and environmental. This interpretation also outlines the levers by which this goal can be achieved. The post-industrial factors of the country's leadership are proposed to be the level and quality of education, spending on science and research, as well as health care, innovation in technological practice, resource conservation, etc., which meets the main goals of sustainable development.

Given the identified features of the post-industrial economy, the factors of its success in domestic and global markets for new goods and services, Orlovska Yu., Vovk M. propose to define the green competitiveness of the post-industrial economy (international competitiveness) as a category combining traditional approach and position concepts of "sustainable development" and "sustainable competitiveness", namely as the ability of the economy to develop unique leadership factors in the post-industrial socioeco-economic space in order to ensure a high level and quality of life with relatively higher productivity of innovative production and highly qualified human resources and thanks to environmentally friendly instruments of economic policy of the state (Orlovska, Vovk, 2014).

It should also be noted that the green economy in terms of classical theory and the formation of Regular Changes of Green Economy System is a multidisciplinary direction, which consists of social, environmental and economic elements, the balance of which makes the economy sustainable. Carl Burkart (Burkart, 2009) defines the green economy on the basis of 6 main sectors, positive changes in which will naturally lead to the sustainability of the entire green economy as a system. These sectors are: renewable energy; green buildings; ecological transport; water resources management; waste management and land management. We believe that concentrating priority efforts in these areas will provide the greatest economic multiplier effects and a corresponding strengthening of welfare and social justice.

\section{Irreversible changes of green economy system}

Based on the UN's definition that the "green economy" is a result-oriented concept aimed at achieving convergence between the three components of sustainable development, the strategy of transition to a "green" economy requires more thorough development of economic levers at the level of both national economies and individual sectors. Irreversible Changes of Green Economy System must be provided. And here the issues of the best type of regulatory mechanism come to the fore: market or administrative (mixed economic and regulation system).

In this context, Potapenko V. writes about market liberalization as a negative factor for the formation of a green economy as a system (Potapenko, 2014, p. 9): "Market self-regulation processes negatively affect social security and the state of the environment. Therefore, UN experts advise to pay attention to the formation of a new green economy, which provides for the growing role of the state and intergovernmental bodies in economic regulation, creating conditions for business development based on new "green" technologies and greening of industries.

Moreover, state policy in the field of green economy should be aimed at protecting the environment and the interests of society. Scientists believe (Vukovic N. etc., 2019) that the most important elements of such public policy are environmental audit, environmental certification and other activities. Note that they coincide with the elements of the "rigid environmental policy" that was proposed in the theories of the "Porter hypothesis" (Porter M., Van der Linde, 1995), the neoclassical environmental concept of "pollution haven theory" (Levinson A., e-sourse), a "resource-based view” theory (Clift R., Wright L., 2000).

According to foreign experience, economically developed countries have achieved significant ecological and economic efficiency, in which state influence has contributed to the convergence of socioeco-economic goals of economic entities. Thus, back in 2008, during the financial crisis and the threat of global recession, the OECD advocated the idea of "green" incentives, especially in areas where large-scale public investment can give impetus to the formation of the green economy (Atkisson, 2011), strengthening its competitiveness. Income and employment growth have been driven by public and private investment, which reduces carbon emissions and pollution, increases energy and resource efficiency, prevents biodiversity loss, and promotes ecosystem services. Such investments need to be supported through targeted public spending, policy reforms and regulatory change.

With this in mind, the implementation and development of environmental policy measures must take into account the possibility of anticipating specific impacts on competitiveness, transition periods of adaptation, possible additional transaction costs. It is also important to take steps to support businesses that incur significant costs in implementing environmental policies. 
In general, any regulation in theoretical and practical terms is considered in terms of its degree of rigidity and shape. In this case, the rigidity of regulation usually involves such basic elements as standards and the severity of their implementation. Environmental standards, according to scientists (Brunel C., Levinson A., 2013; Darnall N., Pavlichev A., e-sourse) should reflect the permissible level of pollution and energy consumption, and the degree of compliance with these standards should be checked by environmental inspections (environmental audit, environmental certification mentioned above etc.).

Governments, businesses and citizens need to move towards balanced development paths, including promoting investment in natural capital (increasing the share of protected areas, strengthening forest protection, etc.), addressing energy and clean food, focusing on land use and land use planning, optimal allocation of limited resources and improved resource management.

\section{Conclusions}

As noted in international studies, the concept of "green economy" can solve the current problems of mankind and provide opportunities for economic development strategy of all peoples for the future. The green economy should be seen as one that increases the well-being of the population and ensures social justice, as well as minimizes environmental externalities. The model of green economy provides a harmonious combination of economic needs of society with the need for constant recovery and preservation of the environment.

The world is on the verge of important decisions about new ways to generate energy and develop our natural resources. The consequences of this choice will affect many future generations. Against the background of growing population in the world and the constant pressure on the natural environment, modern scientists question the need for a technological transition to a greener, cleaner world economy. As the planet's population is expected to reach 9 billion people by 2050 (Marchenko, Mamaliga, 2019), countries must accelerate the pace of effective, environmental economic growth. At the same time, this development of the green economy must be balanced taking into account both resource opportunities on the one hand (human and natural capital) and simultaneously ensuring the three main features of development as such: its direction, regularity and irreversibility of changes in the green economy as a system.

The content and fundamental differences of each of the mentioned features considered in the article require even more in-depth study of the methods of their measurement and assessment of reachability. Additionally, it is necessary to substantiate the system of convenient indicators and/or integrated indices for assessing the development of the green economy; to make attempts to single out groups of countries, regions, etc. at this level in order to determine effective strategies for creating effective conditions for the practical implementation of the principles of green growth and sustainable development.

\section{References:}

Allen, C. (2012). A guidebook to the Green Economy. Issue 1: Green Economy, Green Growth and Low-Carbon Development - history, definitions and a guide to recent publications Division for Sustainable Development / Cameron Allen, Stuart Clouth. New York : UNDESA, Division for Sustainable Development.

Anikina, I., Anikin, A., \& Nozhkina, N. (2017). Green economy as a condition of sustainable development of regions: Assessment of the effect of decoupling on the example of the Volgograd region in the collection: Alternatives to regional development. Conf. Proc. 1, P. 107-114.

Atkisson, A. (2012). OECD Global Forum on Measuring Well-Being for Development and Policy Making / Alan Atkisson. - New Delhi, India - 20 October 2012.25. Towards a Green Economy: Pathways to Sustainable Development and Poverty Eradication. - New York : United Nations Environment Programme. 52 p.

Balkyt, A., \& Tvaronavičien, M. The inclusion of sustainainable development dimension into the competitiveness theory. Available at: http://leidykla.vgtu.lt/conferences/BME_2010/006/pdf/Art-Balkyte_Tvaronaviciene.pdf

Berezhna, Yu. (2012). Kontseptsiia "zelenoi ekonomiky": mizhnarodnyi aspekt [The concept of "green economy": the international aspect]. Scientific notes of the Tauride National University named after V. Vernadsky. Series "Legal Sciences", 25 (64) 1, 210-215.

Brunel, C., \& Levinson, A. (2013). "Measuring Environmental Regulatory Stringency”, OECD Trade and Environment Working Papers, 2013/05, OECD Publishing. Available at: http://dx.doi.org/ 10.1787/5k41t69f6f6d-en175.

Burkart, K. (2009). How do You Define the "Green” Economy. MNN - Mother Nature Network. Available at: https://www.mnn.com/green-tech/research-innovations/blogs/how-do-you-define-the-green-economy

Clift, R., \& Wright, L. (2000). Relationships between Environmental Impacts and Added Value along the Supply Chain. Technological Forecasting and Social Change, 65, 281-295.

Chmyr, O., \& Zakharkevich, N. (2013) “Zelena ekonomika”: sutnist, tsili ta bazovi pryntsypy [Green economy: essence, goals, and basic principles]. Economichnyi visnik Donbasu, 3 (33), 54-62.

Darnall, N., \& Pavlichev, A. Environmental policy tools and firm-level management practices in the United States. Available at: http://www.oecd.org/env/consumption-innovation/35590060.pdf 
David Pearce, Anil Markandya, \& Edward Barbier (1989). Blueprint for a green economy. London: Earthscan Publications ltd. $193 \mathrm{p}$.

DORE. Danish Organisation for Renewable Energy. Available at: https://www.inforse.org/

Orlovskaya, Yu., \& Vovk, M. (2014). Ekoloho-ekonomichna polityka zmitsnennia mizhnarodnoi konkurentospromozhnosti krain YeS [Ecological and economic policy of strengthening the international competitiveness of EU countries]. Dnipropetrovsk.

Galushkina, T., \& Kostetska, K. (2012). "Zelena” ekonomika v sektoralnii modeli rozvytku v Ukraini ["Green economy" in the sectoral model of development in Ukraine]. Economic innovations, 48, 68-77.

Garlytska, D. (2017). Pobudova zelenoi ekonomiky - osnovna skladova yevropeiskoi intehratsii Ukrainy [Building a green economy is a key component of Ukraine's European integration]. Economic analysis: a collection of scientific works of TNEU, 27(2), 15-19.

Levinson, A. Pollution haven hypothesis. Available at: http://faculty.georgetown.edu/aml6/pdfs\&zips/ pollutionhavens.pdf

Marchenko, O., \& Mamaliga, V. (2019). "Zelena” ekonomika: teoretychni aspekty [“Green” economy: theoretical aspects]. Eastern Europe: Economy, Business and Management, 6 (23), 535-541. Available at: http://repository.vsau.org/ getfile.php/23290.pdf

Melnik, L. (2018). Comparative characteristics of the features of traditional and "green" economies. "Green" economy (EU experience and practice of Ukraine in the light of III and IV industrial revolutions). Sumy.

Pearce, D. (1990). Blueprint 2: Greening the world economy. London: Earthscan Publications ltd. 232 p.

Pearce, D. (1994). Blueprint 3: Measuring Sustainable Development. London: Taylor \& Francis Inc. 224 p.

Philosophical Encyclopedic Dictionary (1983) Ch. editor: Ilyichev L., Fedoseev P., Kovalev S., Panov V. Moscow, Sov. Encyclopedia, $840 \mathrm{p}$.

Porter, M., \& Van der Linde (1995). Toward a new conception of the environment-competitiveness relationship. Journal of economic perspective, $9(4), 97-118$.

Potapenko, V. (2014). Transformatsiia systemy pryrodokorystuvannia Ukrainy na zasadakh "zelenoi" ekonomiky: teoriia, metodolohiia, praktyka [Transformation of the Ukrainian nature management system on the basis of "green" economy: theory, methodology, practice]. Dissertation. Kiev.

South Africa's Green Economy Strategy. Available at: http://www.enviropaedia.com/topic/default.php?topic id $=342$

Seventeen goals of sustainable development - the countdown is over (2016). Green Wave. Available at: http://ecoclubua.com/2016/01/17-tsilej-staloho-rozvytku/

Vukovic, N., Pobedinsky, V., Mityagin, S., Drozhzhin, A., \& Mingaleva, Zh. (2019). A Study on Green Economy Indicators and Modeling: Russian Context. Sustainability, 11, 13.

WEForum. Available at: http://www.weforum.org/ 